Historic, archived document

Do not assume content reflects current scientific knowledge, policies, or practices. 



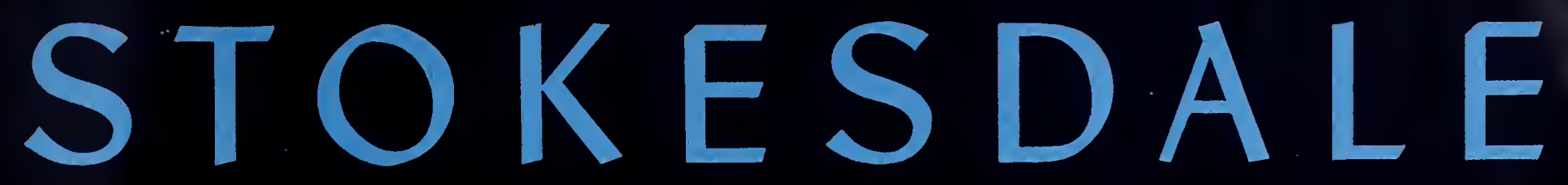

\section{THE TOMATO OF THE YEAR} Dagether with four other distinguished varieties

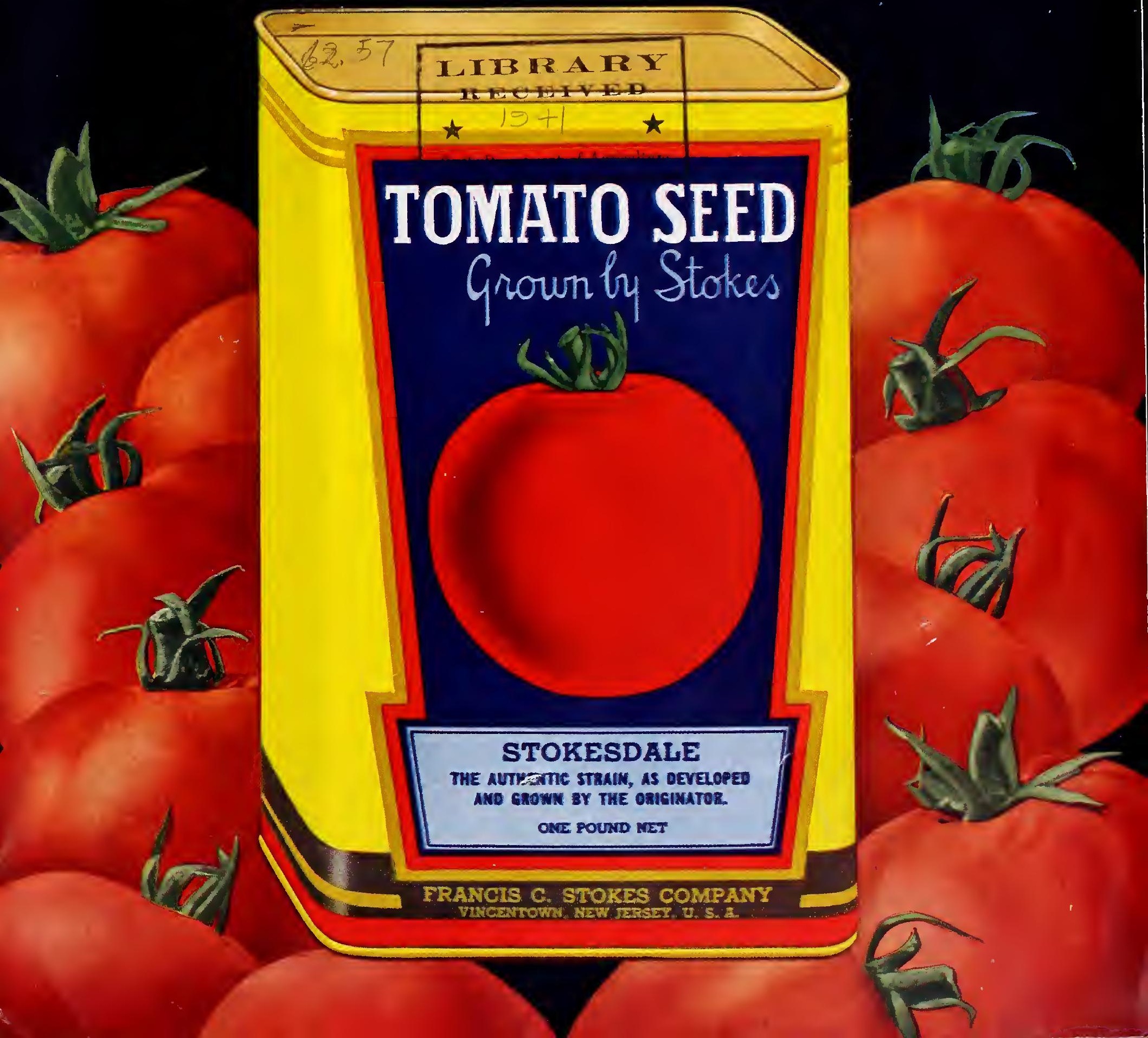




\section{Tomato is the Number One U. S. Vegetable}

\section{It deserves your strongest effort}

THE Tomato Industry in this time of national crisis will quickly take its part in helping to maintain national health and well-being. Your job in this whole dirty business is production-carefully planned production. And in your odd moments sow a few seeds of courage and hope. (The seeds of gloom were planted long ago.)

This Catalog, written by. Tomato men for Tomato men, offers five authentic Stokes strains. We consider them among America's finest. Each is the product of many years' breeding effort, combined with scrupulous care in production and processing. Stokesdale ProvingGrounds, at Vincentown, New Jersey, and our Winter ProvingGrounds at Homestead, Florida, are the background for this intensive effort. Ours is one of the few seed firms in any country devoting its entire time, capital, and strength to Tomatoes.

Your success as a Tomato grower is measured by your ability to secure high production of better than average quality fruit. You will never harvest better than you sow. For all growers who seek the very best in Tomatoes, we suggest that you consult your nearest seed merchant who sells Stokes Tomato Seed. If he cannot be found, you have to $u$ rite to us at Vincentown, New Jersey.

May we also suggest that you act with promptness, for the reason that the demand for our seed continues far ahead of our ability to supply it. Never in our sixty years have we been so nearly sold out in advance of the planting season.

\section{1 - Our Sixtieth Year}
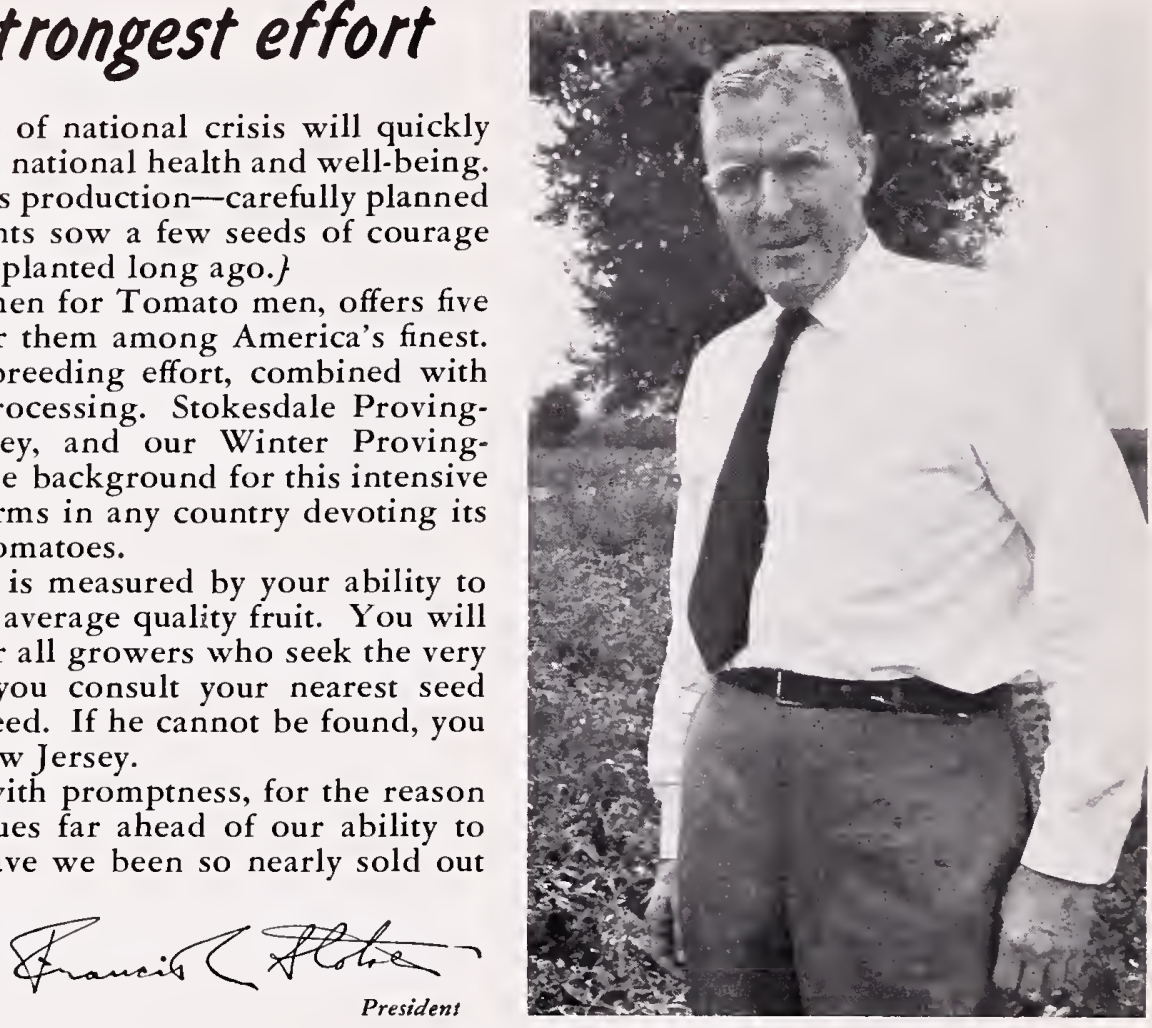

\section{FRANCIS C. STOKES COMPANY Breeders and Growers of Fine Tomato Seed VINCENTOWN, N. J., U. S. A.}

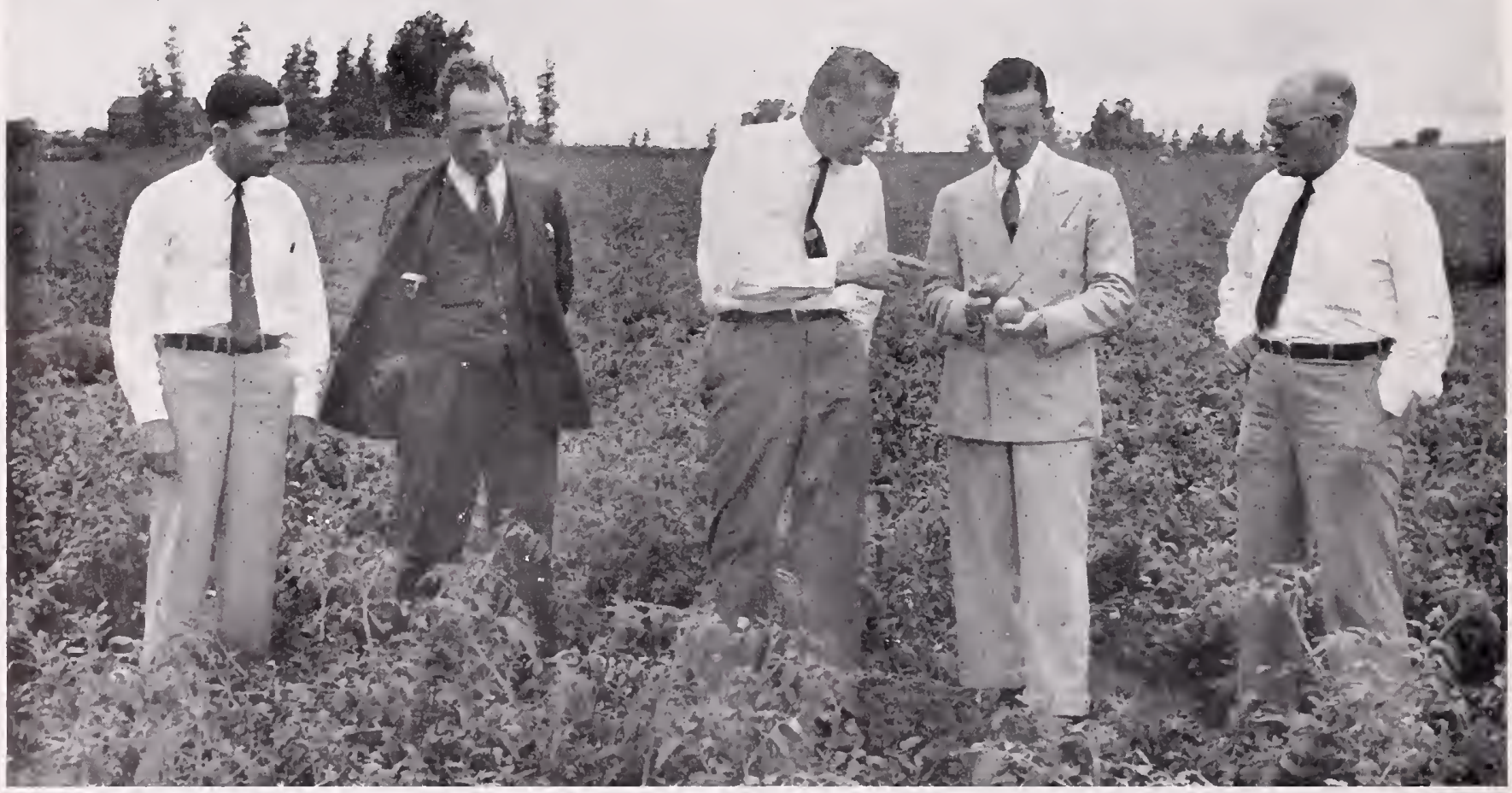

Several hundred Tomato men come to Vincentown each summer to study the work of our Plant Breeding Staff. This photo shows, left to right: E. S. McCall, Savannah, Georgia; Emory Voland, Thiensville, Wisconsin; F. C. Stokes; L. K. Denning, Miami, Florida; H. A. Patterson, Miami, Florida. Won't you plan to visit us in August, 1941 ? 


\section{BULLETIN BOARD - 1941}

SOME MILD BOASTING. Our five varieties of Tomato are: Stokesdale, Master Marglobe, Rutgers, Lange's Earliana, and Valiant. The first three have received the larger part in our breeding etfort. Never have we offered what we consider to be purer and more valuable stocks of these than this year. Several hundred visitors to our establishment at Vincentown this summer confirmed that opinion.

STOKESDALE GROWS UP. With our trade, the Stokesdale Tomato has now reached a place of equal importance with Master Marglobe and Rutgers-a remarkable showing after five years.

PREVIEW OF 1942: Final 1940 Proving-Ground Acreages of Single Plants.

\begin{tabular}{|c|c|c|c|c|c|c|c|}
\hline & & Yield in & Total & $\begin{array}{l}\text { Av, } \\
\text { fru }\end{array}$ & & Av. & Depth \\
\hline Variety & of fruits & $8 / 14$ & in $\mathrm{kg}$. & oz. & kg. & in M.M. & Wid \\
\hline Valiant... & & 3.15 & 4.72 & .140 & 4.9 & 58.5 & \\
\hline Stokesdale ..... & 32 & 2.00 & 4.38 & .138 & 4.8 & 59.7 & \\
\hline Master Marglobe & 23 & .66 & 3.30 &, 146 & 5.1 & 61.6 & 90 \\
\hline Rutgers . . . . . . & $\ldots 26$ & .52 & 4.63 & .162 & 5.6 & 62.2 & 91 \\
\hline
\end{tabular}

MULCHING at Stokesdale in 1940 delayed ripening, reduced both early and total yield, and decreased size of fruit.

PINCHING off early flower clusters is a practice that has proved of no effect whatsoever, either on early yield, total yield, or average weight of fruit. $]$

BONNY BEST-GOOD-BYE. Bonny Best fintroduced by Walter P. Stokes, 1908 f, after a long and useful career, is reluctantly eliminated as Stokes variety. Stokesdale has almost completely replaced it.

COPPER DUST at Stokesdale in 1940 resulted in healthier vines $(4$ points on our scale) and deeper fruit color $(3$ points on our scalef. It is a recommended investment to all who are seeking the higher money.

THE 1940 TALLY. Our 1066 acres harvested at Vincentown this year gave the following results:

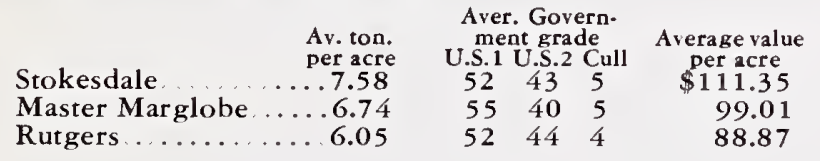

THE WINNERS. Mr. Preston E. Wells, with Stokesdale rated the highest production with 13.29 tons per acre. $\mathrm{Mr}$ Edwin Noller with Master Marglobe rated the highest grade, His grade was: 87 per cent U.S. No. 1,12 per cent U.S. No. 2, and 1 per cent Culls.

STOKESDALE vs. GROTHEN'S. Further comparative tests between Stokesdale and Grothen's Globe confirm our previous findings, namely: that while Grothen's Globe is larger, it is also much flatter. The respective ratios are approximately 90 and 85 per cent. Smoothness and interior solidity are also on the side of Stokesdale.

COME TO HOMESTEAD! Besides the routine testing of our 1940 Vincentown singles at our Homestead ProvingGround, we are making tests of the following new types: Pan-America fU.S.D.A.f; Newell fFlorida Experiment Station); Victor (Michigan Experiment Station and 1940 AllAmerica Seed Selectionsf; The X Tomato (Killef. Our customers are invited to inspect these tests when visiting Florida this winter.

TWO STEMS ARE BETTER. Staking at Stokesdale in 1940 indicated that pruning to two stems, and not one, increased both early and total yield. It also improved fruit-color and leaf-health.

MOST DISTANT VISITORS IN 1940: Maung Hpu, Hla On, San Khin, Shwe Tha Htwe, Rangoon, Burma.

Next most distant visitors in 1940: Sr. Vicente Giaconi M. and family, Santiago, Chile.

\section{ACKNOWLEDGMENTS:}

Photographs by Allen \& Rahn, Moorestown, N. J.

Francis C. Stokes, Jr., Moorestown, N. J.

Engravings by Gatchel \& Manning, Philadelphia, Pa.

Printing by $\mathrm{J}$. Horace McFarland Company, Harrisburg, $\mathrm{Pa}$.

Proving-Ground Co-operators: Wilmer A. Robbins

Howard W. Haines

Samuel Harris all of Vincentown, N. J.

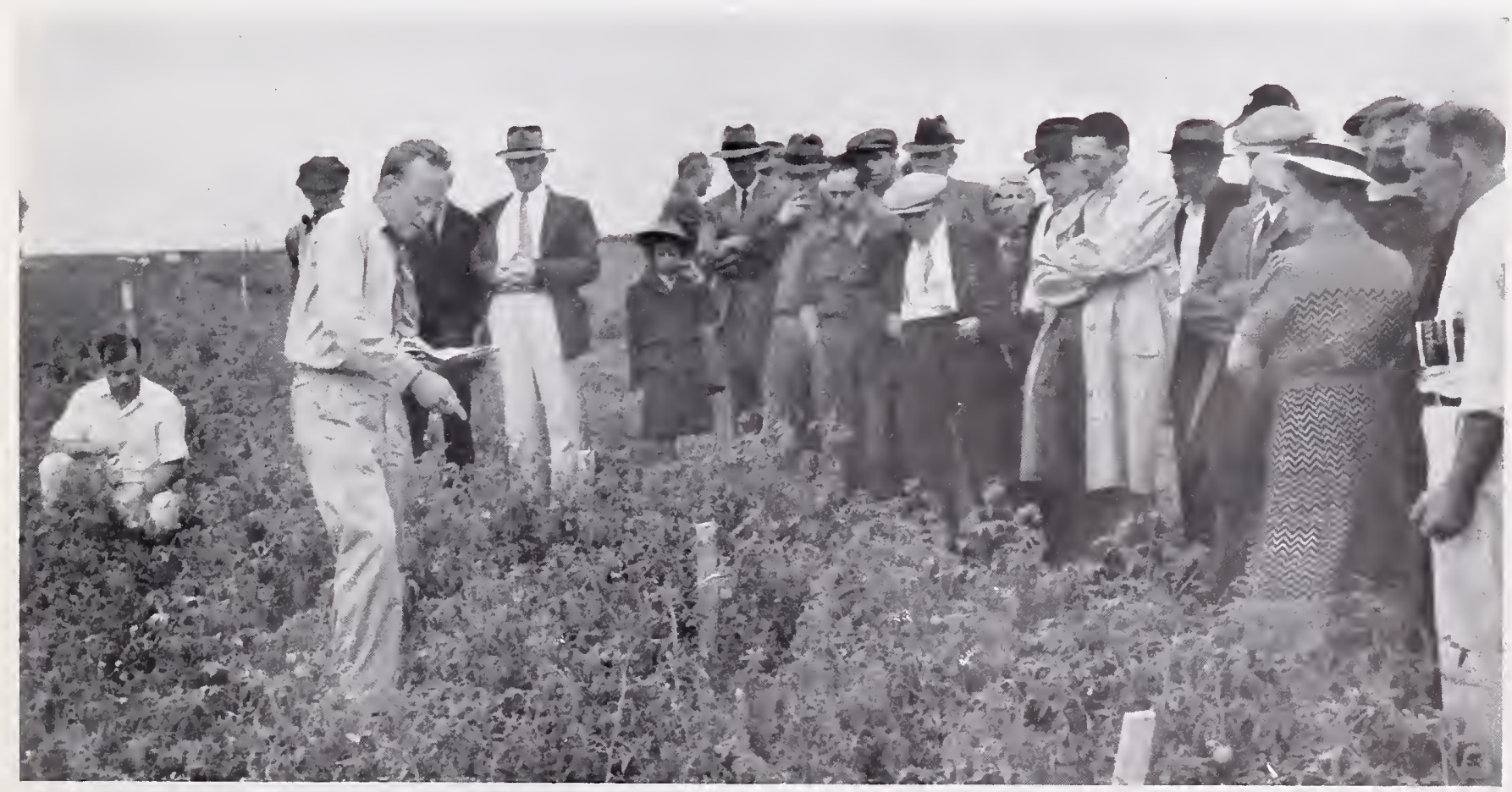

Our 1940 Tomato Field Day was held on August 16. All Tomato growers are invited. Mr. A. A. Foster is here shown explaining strain differences. Stokesdale Proving.Ground is one of the largest experimental fields in this country devoted entirely to Tomatoes, and Tomato problem 


\section{STOKESD A LE-The Tomato of the Year... for the green-wrap shipper}

$\mathrm{T}$ HE success of Stokesdale is due to its maturing a 6-ounce Tomato of streamline proportions one week earlier than the Marglobe group. As such, it is filling an important place in the industry. Perhaps the most unusual factor about Stokesdale is its wide adaptability. We were confident that there was a place for it in the short-season areas of the northerntier states and in the higher altitudes. However, we have been greatly impressed with its success over a much wider field. In only five years it has come to be rated as perhaps the first Tomato of the Lower Rio Grande Valley of Texas. It has also proved extremely profitable to the green-wrap trade of Florida, Georgia and the Carolinas. Here in New Jersey it turned in a profit to our contract growers of $\$ 111.35$ per acre as against $\$ 99.01$ for Master Marglobe and $\$ 88.87$ for Rutgers.

Here, then, is the Stokesdale Tomato, 1941 model: It is now in its ninth generation. The vine coverage is adequate for all normal temperatures. Government inspectors gave it as their opinion that the present strain of Stokesdale was the purest of any we are offering. We now claim a depth-to-width ratio of 90 per cent, an average weight of 6 ounces, and an interior equal to either Marglobe or Rutgers.

Under certain circumstances, Stokesdale has not always developed satisfactory size, and experience has shown that it must be well fertilized and supplied with normal moisture.

There are three outstanding factors about the acceptance of Stokesdale.

1. Its maturity in the Bonny Best season.

2. Its brilliant, smooth, uniform appearance.

3. Its unusually heavy yield per acre.

If you do not know Stokesdale, we advise full-size tests of it under your conditions. For many of our customers it has completely revised their entire variety schedule. It is not at all unlikely that you will find in it a new source of profit.

\section{Price, postpaid: Trade pkt. 25 cts.; oz. 50 cts.; 1/4lb. \$1.50; lb. \$5; 5 lbs. $\$ 22.50$}

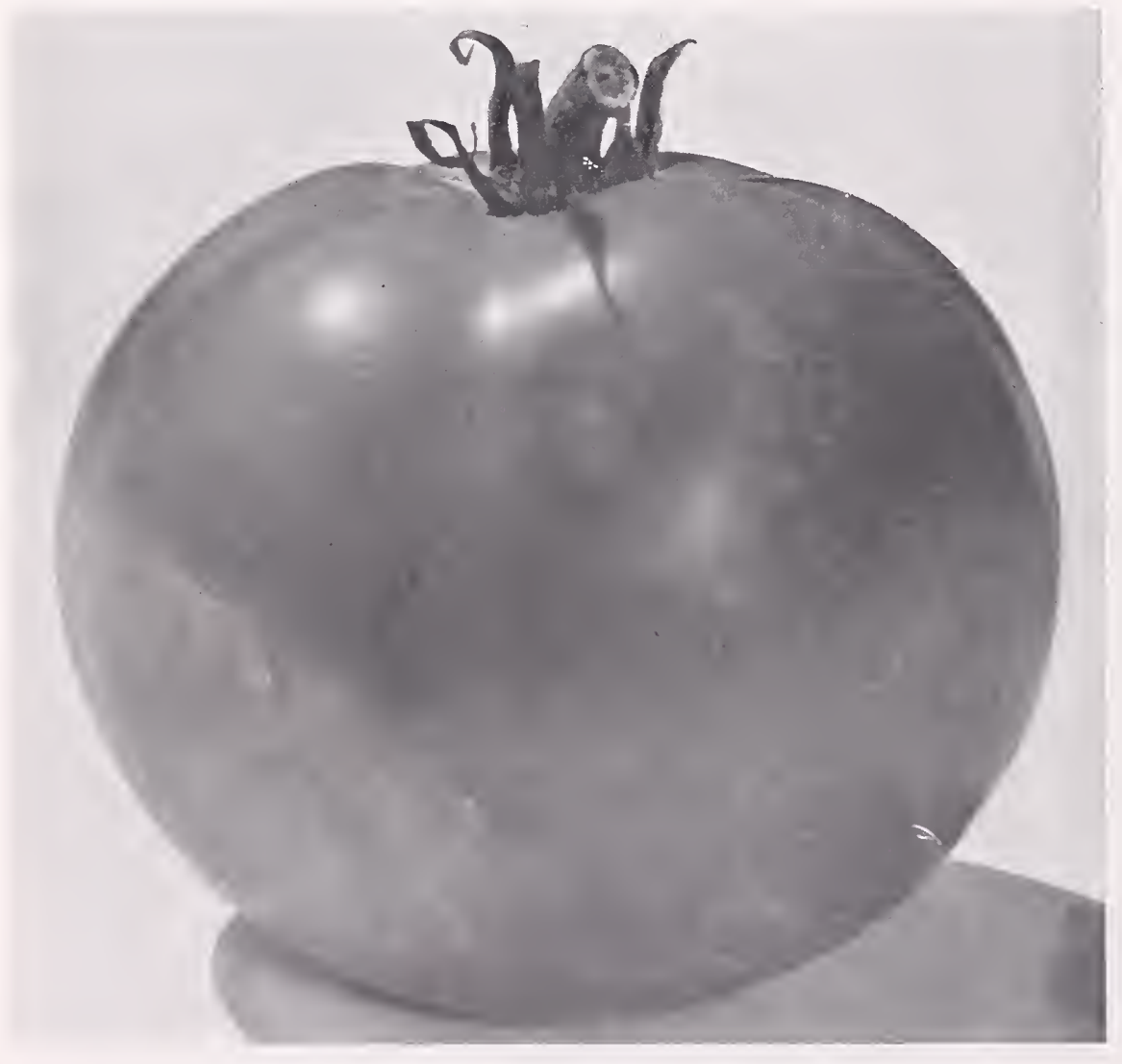

Stokesdale was very good under practically all conditions. In several of the rural counties in central Pennsylvania, such as Cleartield, Jefferson, season is , it was suce the Personally, in looking over rhat a ler consider the early and second-early varieties, I believe that Stokesdale heads be list Bonny Best, John Baer, Chalk's Jewel, Pritchard, and otbers of that particular group, Stokesdale is also a little earlier and yields very heavy. -W. B. N., State College, $\mathrm{Pa}$

We are glad to tell you our experience witb your Valiant and Stokesdale. Tomato seed. We consider them the best varieties we have ever grown. They are very solid, have an excellent flavor and are prolific and we expect to continue to grow these varieties.-M. G. J., Jr., Tunkhannock, $\mathrm{Pa}$.

Stokesdale and Marglobe were both fine Stokesdale yielded tremendously. We sold over 500 half bushels from 900 plants. This doesn't seem possible but it's an actual fact. set late and cracked quite badly.-J. W., Mystic, Conn.

We have beavy rocky soil but Stokesdale did very well this year. It is very productive. I don't think I will ever raise any other Tomato but Stokesdale. We also had Rutgers. It did pretty good but not as well as Stokesdale. and I am very pleased that I have found the right Tomato to grow. Thanks to you. $-S$. S., West Springfield,
Mass.

Stokesdale produced more than Rutgers, Master Marglobe, Pritchard, and Bonny Best-fruits were larger and no cracks. It is the ideal Tomato for tbis territory. Under normal conditions I believe it will break all production records. Also proved to be the best-quality Tomato that has ever been grown in the Middle West.-H. A., Hiawatha. Kans.

Average weight, 6 ounces. Ratio of depth to width, 90 per cent.

Average number of fruit, 32. Days to maturity, 112. 


\section{S T O K E S D A LE - A canning variety of acknowledged importance... for the Northern States}

$\mathrm{T}$ HE extraordinary results with Stokesdale among the canners in the northern-tier states has again shown the real worth of the variety to the canning industry there. There are many points in its favor. The fact that in normal seasons it will allow full maturity is the primary one, but this is also supported by two other factors-unusually heavy production, combined with a most pleasing flavor.

While acknowledging that Master Marglobe and Rutgers develop a more vigorous vine type, it is our experience that the flavor of Stokesdale is superior to either of these, a point which manufacturers of Tomato juice may well give consideration to.

Packers of whole Tomatoes will find that Stokesdale has a much more solid interior than Tomatoes of the Bonny Best type. Size also is greatly in favor of
Stokesdale, which may average as much as 2 ounces heavier than Bonny Best.

The wide acceptance of Stokesdale has brought an expected result: It has so completely replaced Bonny Best that although that Tomato was our company's introduction (Walter P. Stokes, 1908) we are now, with reluctance, discontinuing the variety.

If Stokesdale is not already included in your canning acreage, we urge that you give our stock a trial this year. This recommendation is made with the knowledge that it has performed well for several of the very largest manufacturers of Tomatoes and Tomato products in the Northern States. Successive tests of Stokesdale in the Experiment Stations of those states have confirmed this experience.

\section{Price, postpaid: Trade pkt. 25 cts.; oz. 50 cts.; 1/4 Ib. \$1.50; lb. \$5; 5 lbs. $\$ 22.50$}

\section{FERTILIZER RECOMMENDATIONS FOR STOKESDALE}

For Stokesdale, we recommend a 1000-pound application of 0-16-0 or 2-16-0 with a side dressing of 400 pounds of 10-0-15 soon after plants are set, and the same amounts four weeks later. Stokesdale needs liberal early feeding because of its tendency to set so heavily in the early season.

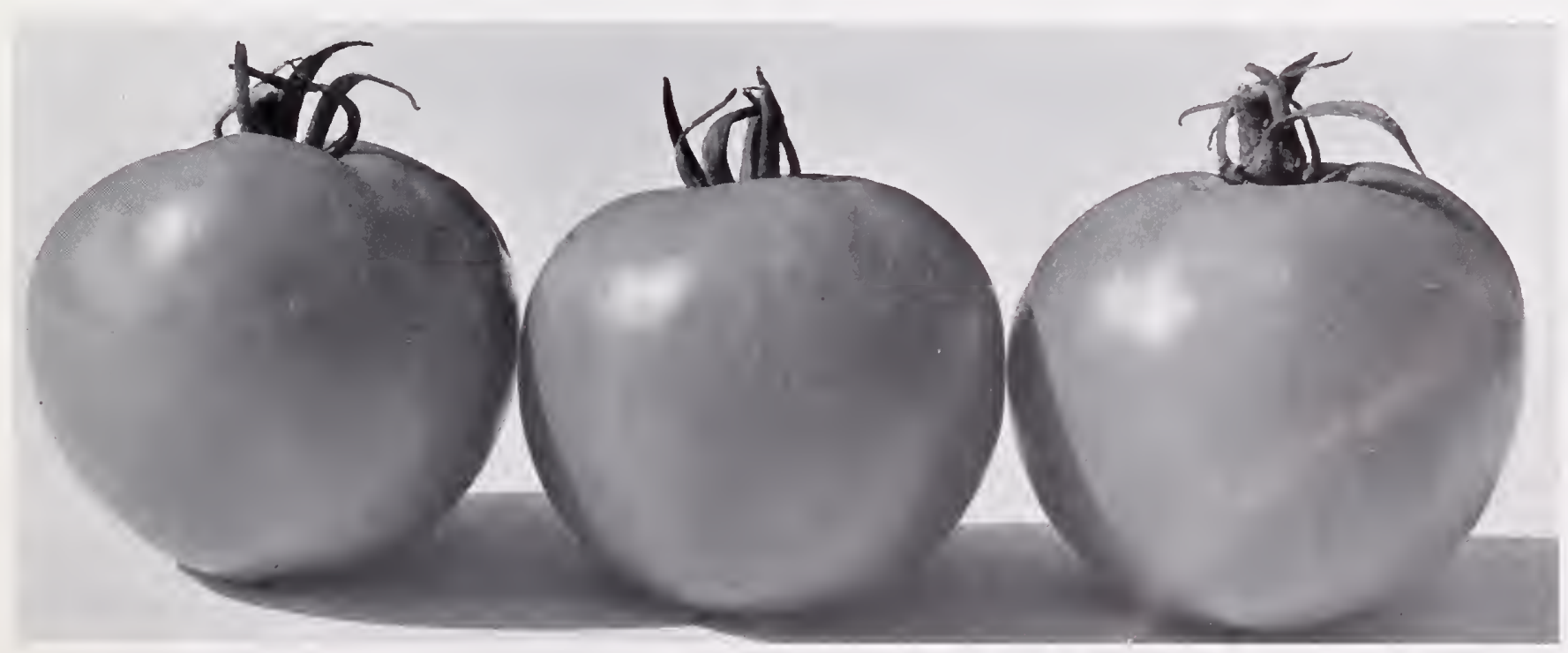

We had very fine results from the Stokesdale seed that we received from you. Some of our acreage turned out 15 tons per acre of good firm fruit. When we get ready to take on our requirements for another season, we shall contact you for more seed.-W $\mathrm{m}$. Bewley, Middleport, N. Y.

I surely am more than pleased with the results I had the past three years with the Stokesdale variety. It surpasses any others I have raised in quality, size, and yield.-E. V., Thiensville, Wisc.

I doubt if you can ever improve on the Stokesdale Tomato any more than I think you can ever issue a more attractive catalogue than you did for the year 1938. Both seem to me as near perfection as is possible. For me the Stokesdale proved much better than the Valiant-stronger plants, better foliage, and more solid fruit.-S. N. G., Ascutney, Vt.
Valiant and Stokesdale have performed very well for me here in spite of the extremely dry weather. They produced a large crop of large, smooth Tomatoes that anyone could pick and sell and feel that his customer was getting his money's worth both in size and quality. Pritchard is another good Tomato--A. L. M., Brookings., S. D.

Valiant and Stokesdale, here in Missoula, Mont., were wonderful. They began to ripen July 20) and at this date (October 18.1938 ) they are still full of ripe and green Tomatoes, I had no culls from Valiant or Stokesdale. , Missoula, Mont.

Stokesdale made a creditable showing again this season, being second to Break o'Day and Bonny Best, in yield and earlier fruit.-W. H. F., Weslaco, Texas. 


\section{STOKESDALE-Second-Early. Productive . Profitable}

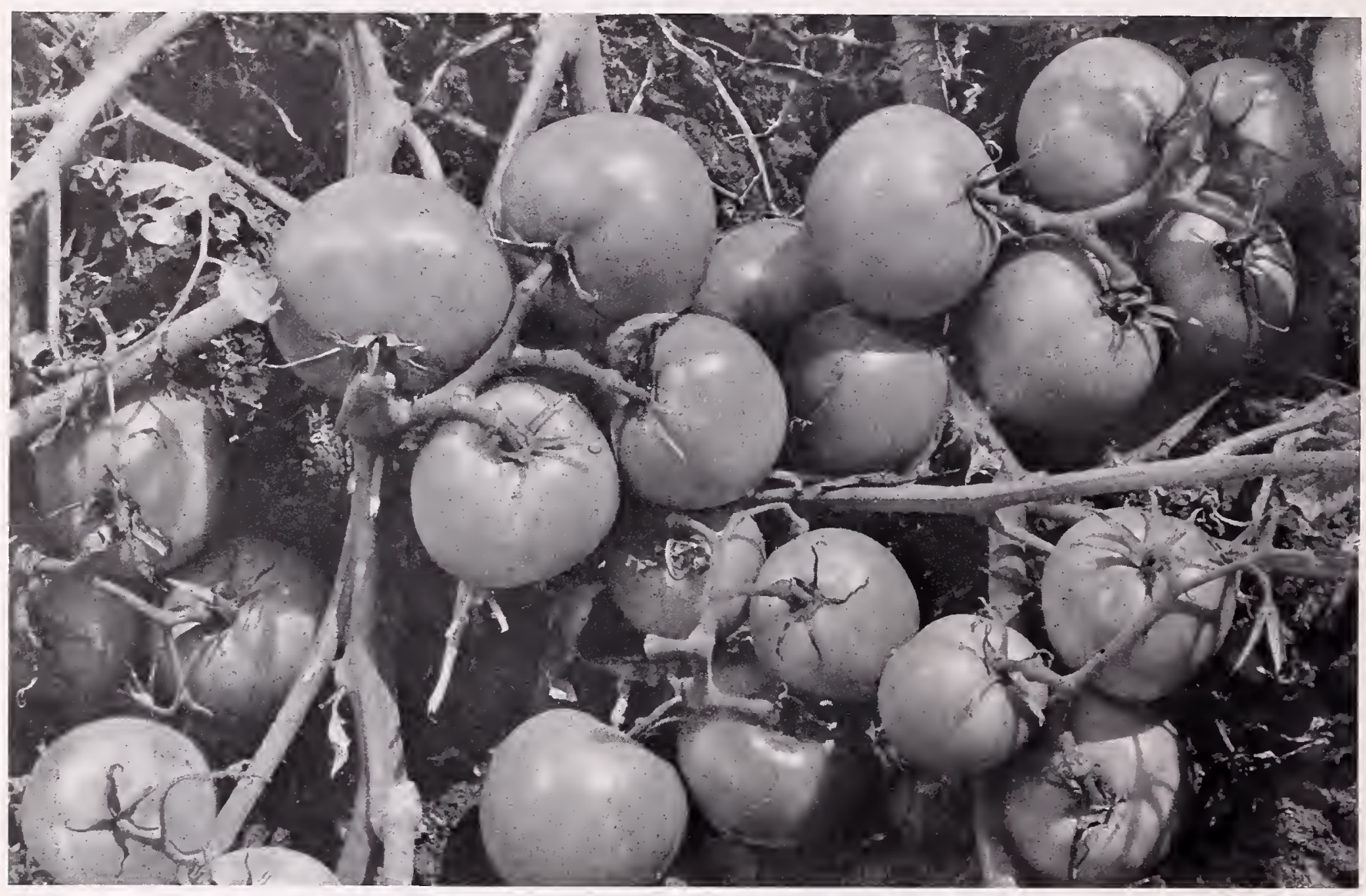

August, 1940, photo Stokesdale plant, unposed, except that foliage was removed to show fruit.

This emphasizes two points-smoothness of fruit and enormous production

Suggested

Soil-

\section{Management}

for

\section{High Yields}

-
$\mathrm{T}$ HE problem of the relation of soil to Tomatogrowth is one of the most intricate that a grower has to face. He can no longer spread an occasional load of manure and leave the rest to nature. Although that worked when manure was plentiful and Tomato acreage small, today's extensive agriculture depletes our soils so rapidly that manure alone cannot keep them fit. Every grower ought to maintain his soil at least at the fertility level at which he finds it. Many find it profitable to raise the level considerably.

Plants need, in the first place, water and air If both are to be present in the soil in proper quantities there must be enough humus or decayed organic matter to regulate the physical condition. Sandy soils containing humus will retain more water, while heavy soils, on the other hand, will drain better if humus is present. This equalizing effect on the water supply has its indirect effect on aeration, for soils that do not puddle contain enough air for plant-roots. That is why progressive farmers conserve organic matter. Hester* suggests a minimum content of 1 per cent in sands, $11 \%$ per cent in sandy loams, and 2 per cent in loams. Manure is an excellent source, but next best is a green-manuring program. Crop-rotation and the turning under of vegetation will keep soil organic matter high. Your county agricultural agent knows particular rotations suited to your region.

Among the nutrients plants need, nitrogen rates high in importance. The quantity carried by organic matter is usually insufficient and its form unavailable. During the second and third months after transplanting, Tomato plants need nitrogen in larger quantities than the soil can supply it. Since nitrogen-carrying fertilizers in the soil at transplanting time can be injurious, and since much leaches away before the plant needs it, nitrogen should be side dressed.

Phosphorus is the element which is most commonly deficient in soils. Tomatoes respond favorably to large quantities of superphosphate. Mixed *Dr. Jackson B. Hester in Campbell Soup Co. Bulletin 1, "The Soil Side of Tomato Growing." with the soil, it will not injure young plants. Apply it before or at transplanting time, for the plant uses it immediately.

Potassium is the third important chemical fertilizer commonly added to the soil. It resembles nitrogen in that large quantities in the soil at setting-time injure the plants. Tomatoes do not use it until the second and third months after transplanting.

We therefore suggest that in applying your fertilizer this year you use an analysis such as 0-16-0 or 2-16-0 at plant-setting time and 10-0-15 as a side dressing, four weeks, and again, eight weeks after transplanting. The quantities vary in different regions. In New Jersey the most successful growers use 1000 pounds $0-16-0$ and two side dressings-400 pounds per acre eachof 10-0-15. We urge those who think this procedure too costly to try it on a few plants.

There is much talk about the need of other elements such as boron, copper, manganese, and zinc. The soils where these are deficient are so limited in area that it is not wise for most farmers to buy fertilizers containing them. An excess might be injurious.

There are two more elements, calcium and magnesium, which are often added to soils. These are usually called soil amendments rather than fertilizers. The reason is that their chief use is in changing soil acidity, although plants use them in small quantities. Their addition to the soil as lime produces a chemical condition which helps the plant obtain other elements, especially phosphorus. Since a pH of between 6 . and 7 . is the best acidity for Tomatoes, most of our soils are too acid. That means that, generally, lime helps. Do not lime your soil unless a test shows it is needed, for an excess is more harmful than a deficiency. 


\section{S TOKE S D A LE-Like all other Tomatoes... must be fed, if you want size}

We suggest the following routine with all varieties, but especially so with Stokesdale:

Use a nutrient solution in the transplanting water. We have seen some outstanding results from this practice in 1940. Two to four pounds of the following mixture to 50 gallons of water is recommended.

MIXTURE:

4 parts by weight of Superphosphate $(\mathbf{P} 205)$

1 part by weight of Calnitro $(20 \% \mathrm{~N})$

1 part by weight of Nitrate of Potash $\left(13.5 \% \mathbf{N}-46 \% \mathbf{K}_{2} \mathrm{O} /\right.$

Col. Sayre, of the Geneva, New York, Experiment Station, recommends $1 / 4$ pint per plant $(91$ gallons per acref of the following: 2 parts Ammophos 1 part Nitrate of Potash 8 pounds in 50 gallons water
This fertilizer being in solution will give the plants a quick start and will not injure the roots. This mixture can be procured from your fertilizer dealer.

If the transplanting solution is not used, a side dressing of Nitrogen should be applied as soon as the plants are set.

We also wish to emphasize the importance of lime for Tomatoes on all soils where the $\mathrm{pH}$ is lower than 5.8 or 6.0 . Lime supplies calcium and magnesium which are very important for Tomatoes and also makes other plant nutrients more available.

When side dressing late in the season, place the fertilizer well away from the plants for best results.

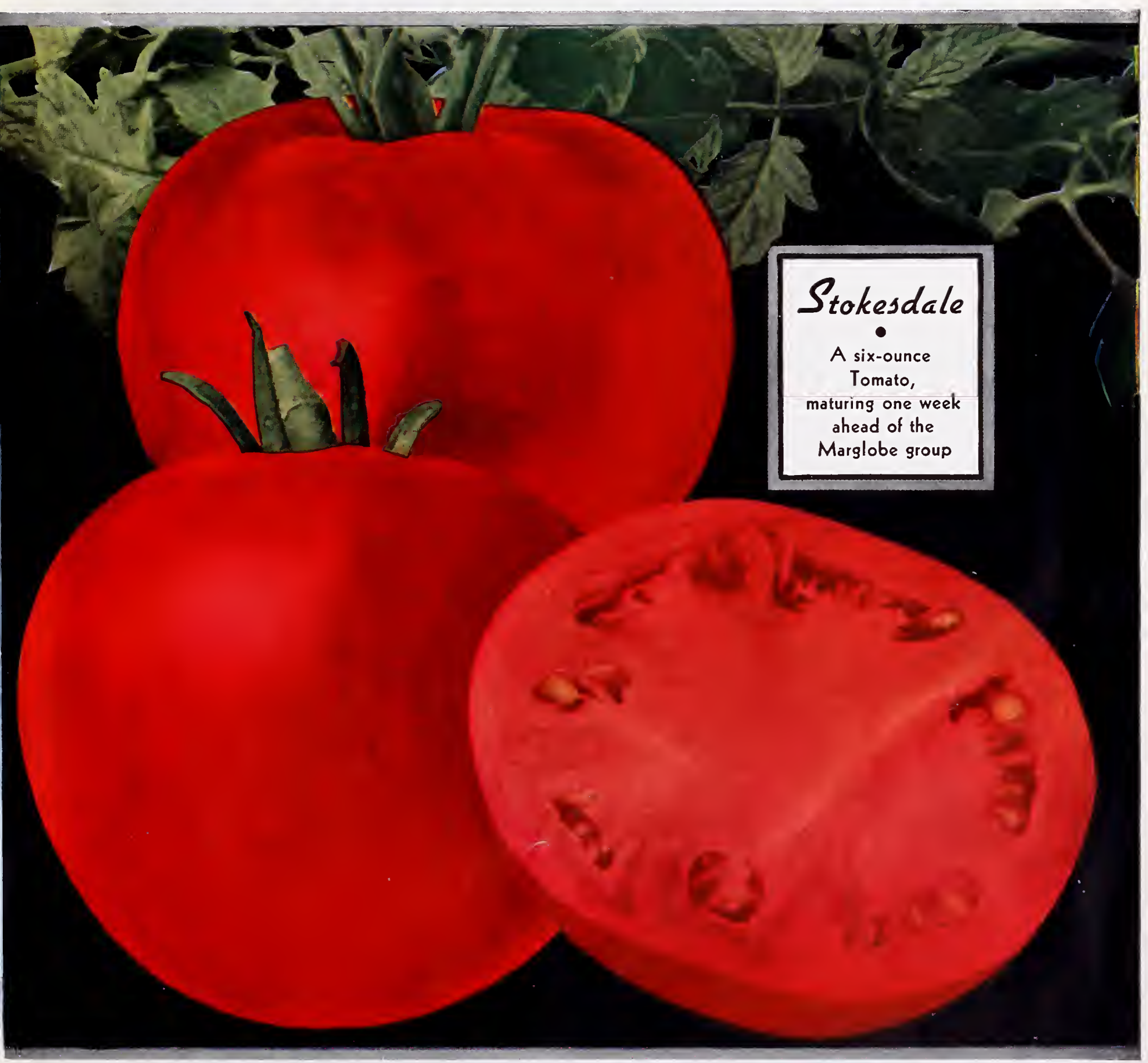




\section{MASTER MARGLOBE-17th Generation. Generally conceded to be America's foremost shipping Tomato}

$T$ HE high money in the northern markets goes to the Tomatoes that are uniformly deep, large, and solid. If our Company has had any influence in the Tomato industry it has been in the direction of deeper Tomatoesthe fruits that carry the extra slice. The consumer has fixed this standard for she invariably chooses a Tomato that will slice well. Knowing this, the market-man invariably chooses the deeper fruit. For years this Company has stressed the importance of depth-to-width ratio above all other Proving-Ground readings. The Tomato buyer watches two other points also: He wants $5 \times 6$ or $6 \times 6$ fruit, and he guards against loss by buying solid Tomatoes. He is constantly on the lookout for puffs.

As Tomato breeders, we have worked hard and long over Master Marglobe. There have been disappointments, as there always are, but in the long run we have gained ground. After seventeen plant generations, with an expenditure of approximately $\$ 30,000$, Master Marglobe has developed an average depth-to-width ratio of $90 \%$ - a most unusual figure. The solid interior, as shown in the cut on the opposite page, is characteristic of the Marglobe parent, Merveille de Marche. Fred Pritchard's magic touch started all of this back in the days of the first World War. What he sought and found was resistance to disease. His Livingston Globe $\times$ Marvel cross has brought millions of dollars to the Tomato industry.

Our part in this development has been a humble one. Perhaps the best to be said for it is consistency of effort. Through war and peace, through good times and bad, we have never relaxed on the breeding program of Master Marglobe. The results tell their own story. The 1940 stock comes nearer our ideal shipping Tomato than any we have ever produced, and that goes for all the qualities, including size, depth, solidity, color and, uniformity of vine-coverage.

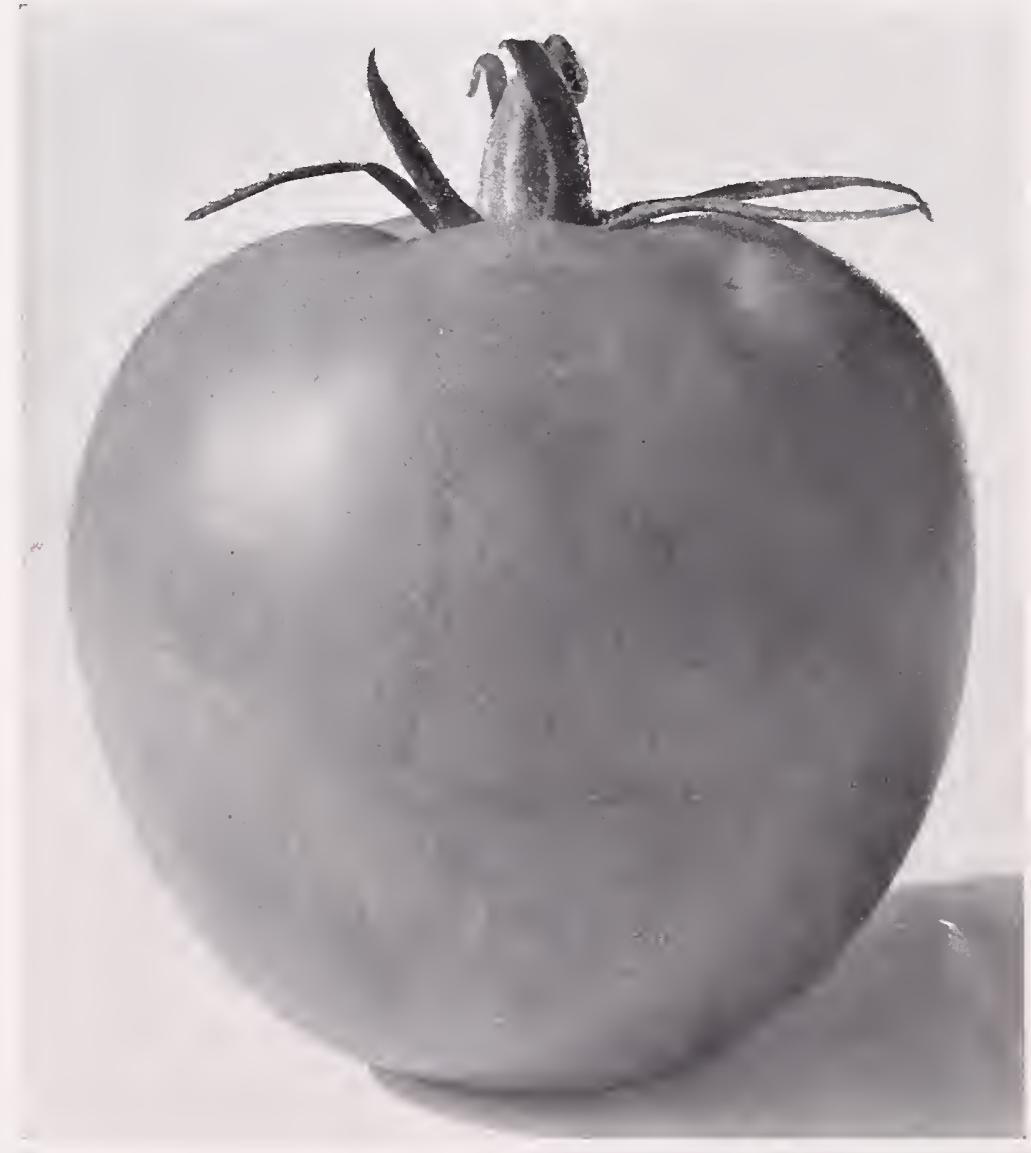

Average weight, 6 ounces. Ratio depth-to-width, 90 per cent. Average number of fruits, 23. Days to maturity, 118.
When you buy Master Marglobe in our tamper-proof canister you are getting our prize product. Perhaps we may be pardoned for believing it represents the finest breeding work in America. If you have planted unidentified stocks of Marglobe and have been disappointed, don't condemn the variety until you have tried Stokes Master Marglobe-crop 1940. Our acreage under New Jersey Department of Agriculture certification represents an enormous effort going back thirteen continuous years.

\section{Price, postpaid: Trade pkt. 25 cts.; oz. 50 cts.; 1/4lb. \$1.50; lb. \$5; 5 lbs. $\$ 22.50$}

My Tomatoes, Master Marglobe, Valiant. and Stokesdale, set an immense quantity of green fruit and I did have a fair crop. Thave a small retail greenhouse and sell about 20,000 was superior as to smoothness, size, flavor, and solidity. consider your trains highly superior and plant them until something better is developed.-H. A. W.. Halstead, $\mathrm{Pa}$.

Now the Master Marglobe was different. I had given the neighbors quite a few of these plants and they tell me the were as hine Tomatoes as they ever had. The most favorable comment was in regard to its being such a fleshy Tomato with a remarkably thick side wall and such a small seed
cavity.-C. A. Y., Lancaster, Pa.

From my soil no variety I have tried can touch Marglobe. The seed and plants of that variety were 100 per cent satis. factory.-L. C., Oceanside, N. Y. 


\section{MASTER MARGLOBE - The Tomato with the extra slice}

\section{FOR GREENHOUSE FORCING}

\section{Plant These Elite Stocks from Stokesdale Proving Grounds}

G

REENHOUSE men, and other growers who operate on an intensive scale, find that these Proving-Ground Stocks, even at these obviously higher prices, are bargains. This seed is taken directly from our foundation-planting stock and is the same as that we plant for our own pedigreed-seed acreage. It represents the cream of the Stokes crop. It is certified, disinfected, and handled with special care. Most of it is sold in ounces or in fractional ounces.

Each year we supply important quantities of this elite seed to the forcing trade-a clear indication that the extra investment pays its way. The high-production expense of greenhouse Tomatoes requires that only the most perfect seed-stock be used. These six Tomatoes offer a reasonable variety range. Because of varying growing and market conditions, we recommend that two, if not three, of these varieties should be planted. The following are now available:

\section{VALIANT STOKESDALE BONNY BEST}

PRITCHARD RUTGERS MASTER MARGLOBE

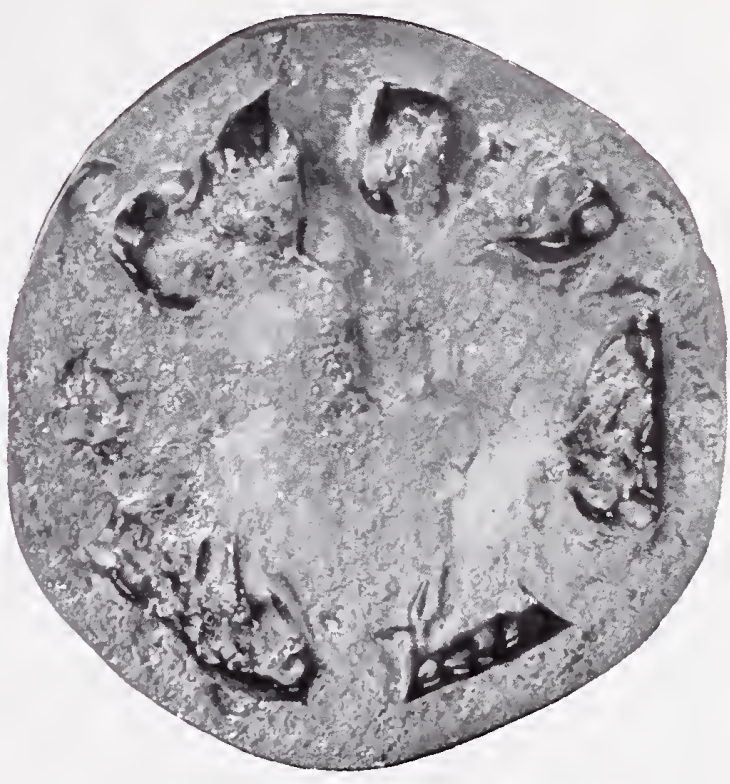

The interior structure of Master Marglobe has been bred for great solidity

Price, postpaid, of Greenhouse Forcing Stock: Trade pkt. \$1; 1/40z. \$1.75; $1 / 202 . \$ 3$; oz. \$5; $1 / 4$ lb. $\$ 17.50$

\section{FERTILIZER RECOMMENDATIONS FOR MASTER MARGLOBE AND RUTGERS}

We recommend 1000 pounds per acre of $0-16-0$ or 2-16-0, either under the row or in bands near the row. Very good results have also been obtained from broadcasting this Fertilizer either before or after the ground is plowed. A side dressing of 400 pounds of 10-0-15 about three weeks after the plants are set and again when early-set fruit is the size of eggs, or as late as you can go through the fields. The 10-0-15 may be split in three applications, if desired. Master Marglobe requires ample plant nutrients late in the season. Maturity is retarded by early and heavy applications of Nitrogen.

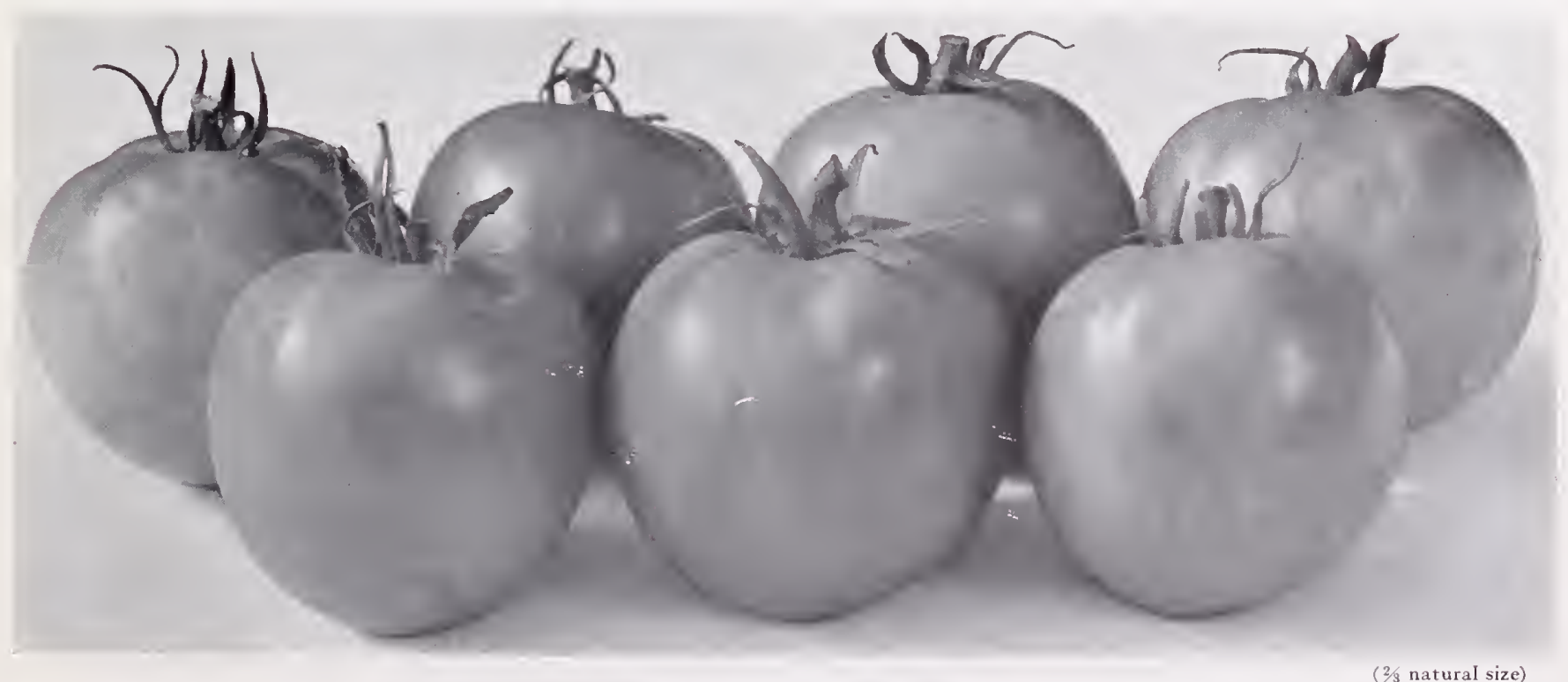




\section{MASTER MARGLOBE-The Elite Strain of the Main-season Group}

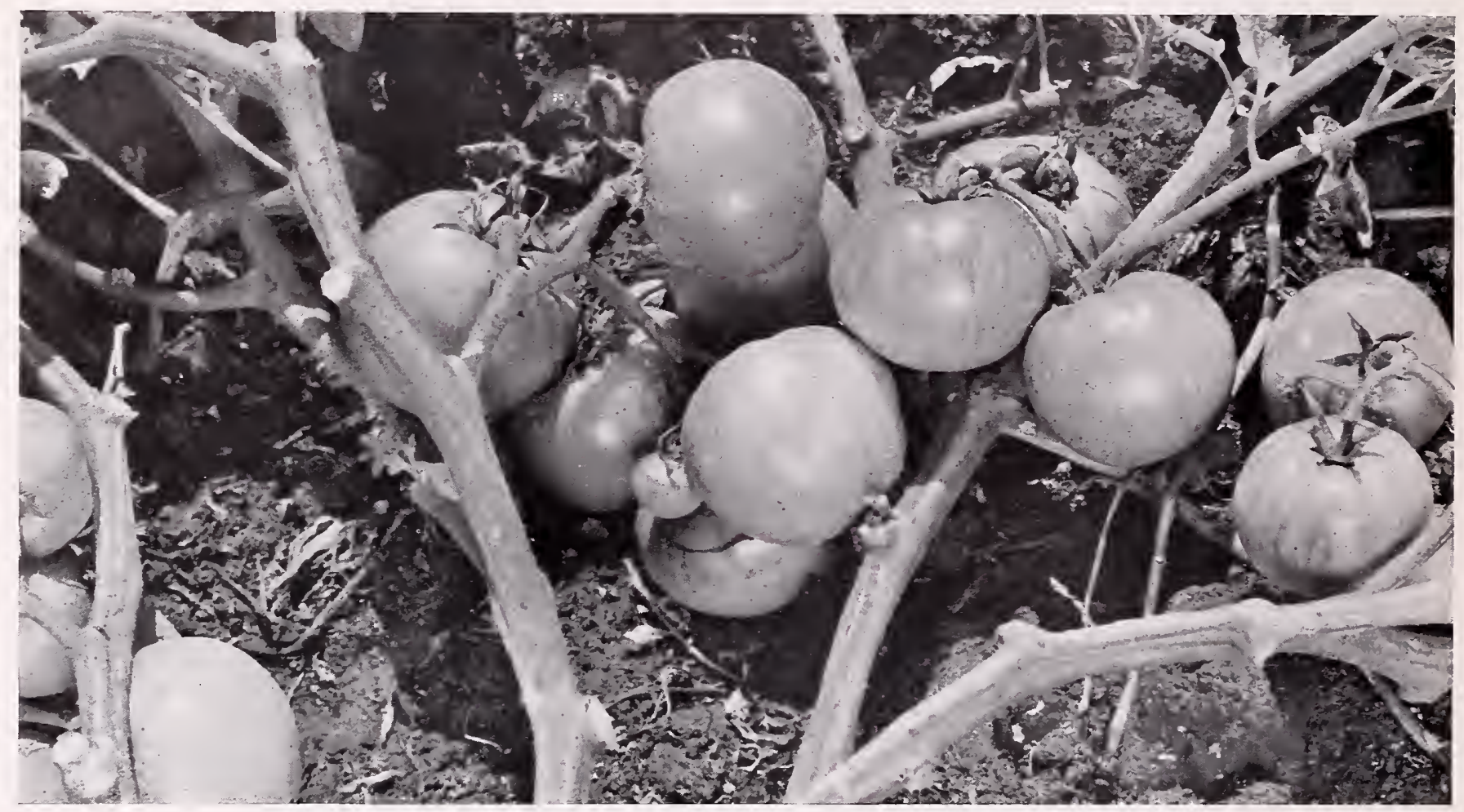

August, 1940. Photo Master Marglobe plant, unposed, except that foliage was removed to show fruit. Two hands had been gathered when this picture was taken.

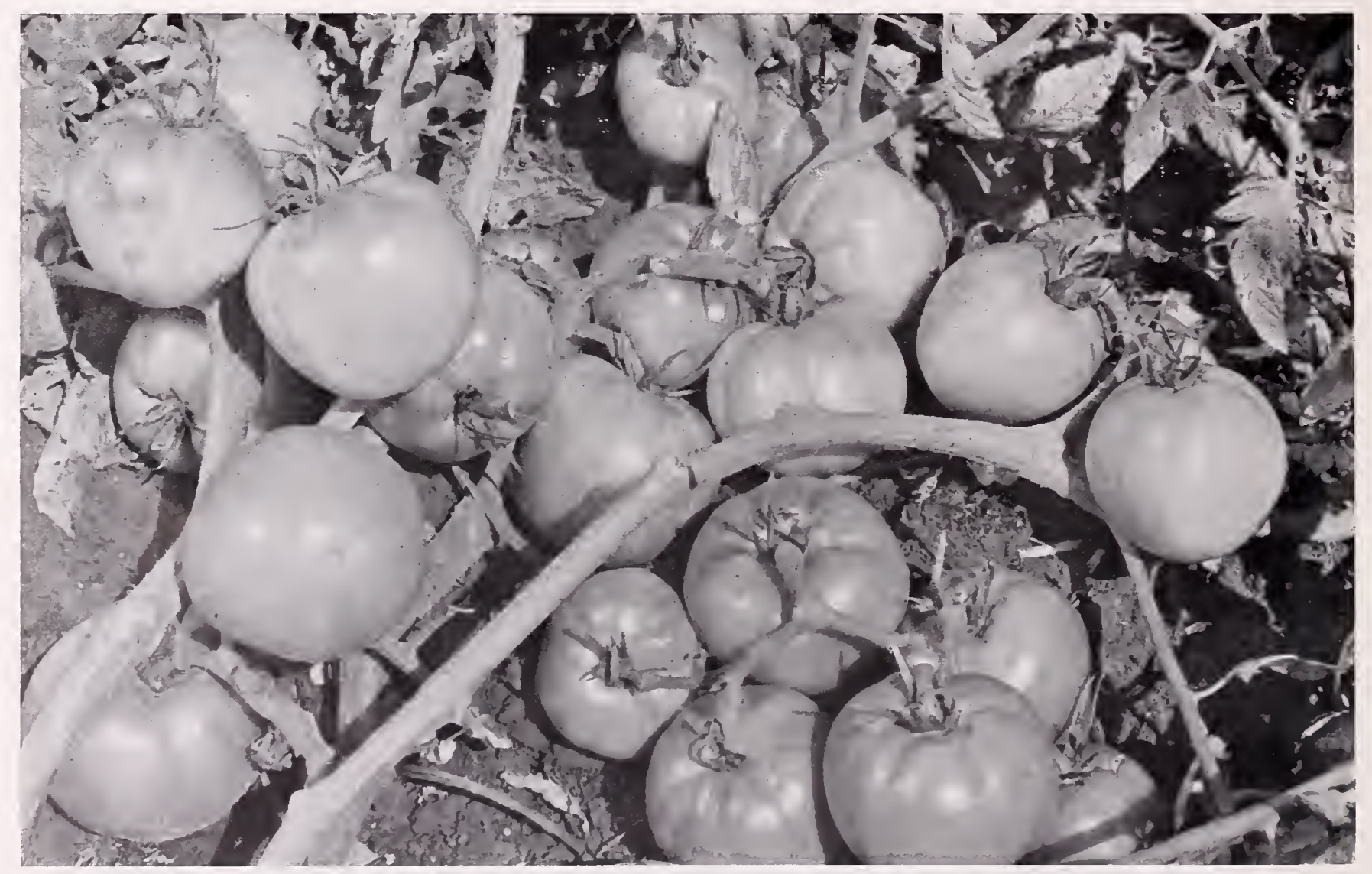

August, 1940. Photo Rutgers plant, unposed, except that foliage was removed to show fruit. This photograph 


\section{Master Marglobe- $\begin{gathered}\text { DeEP } \\ \text { sollo }\end{gathered}$}

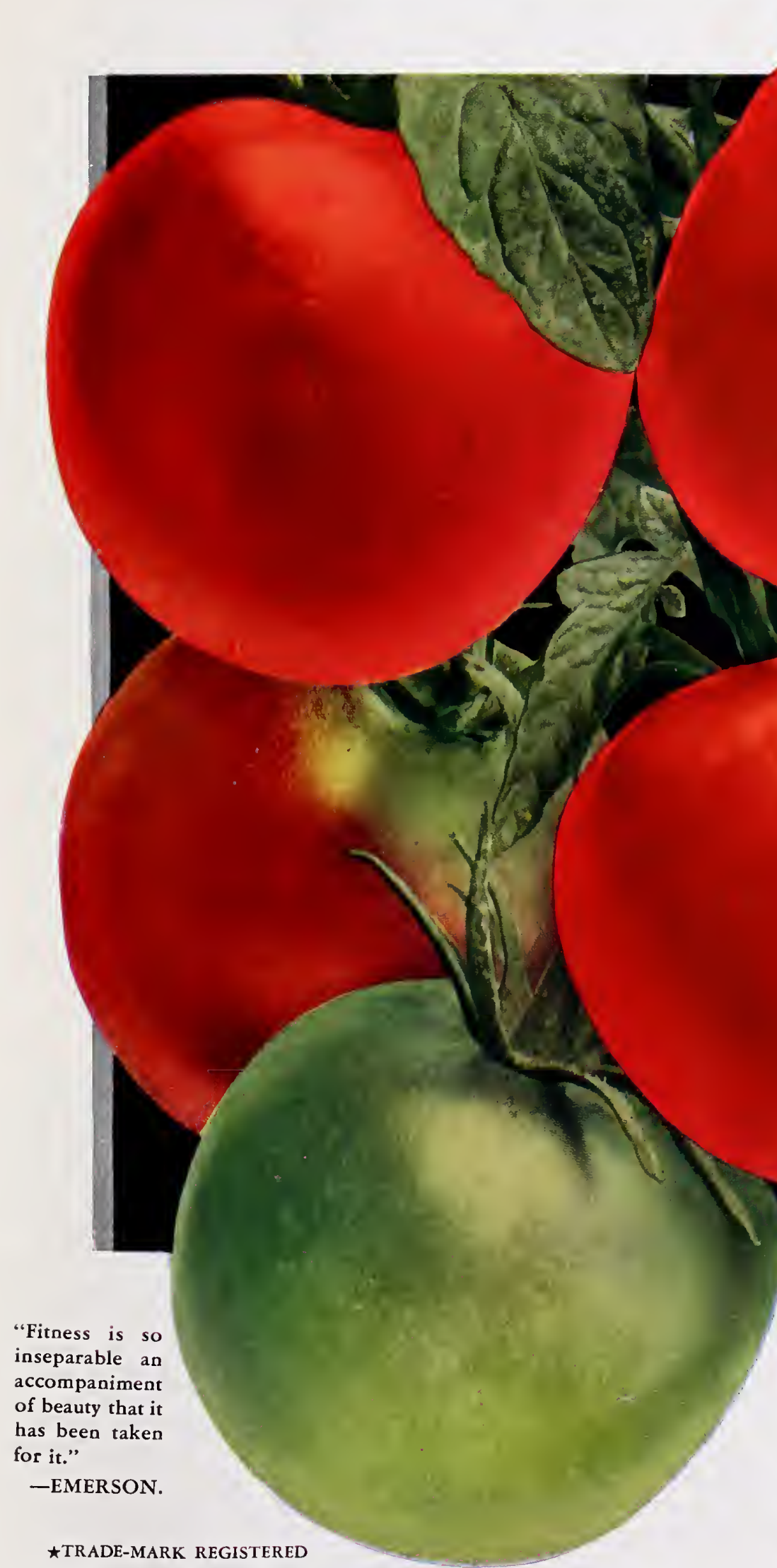

RESISTANT

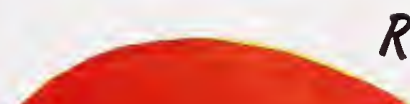




\section{RUTGERS-The Stokes strain is deep and smooth}

IN RUTGERS, Prof. L. G. Schermerhorn, of the New Jersey State Experiment Station, developed an extremely valuable Tomato. Its acceptance over a wide area and for many purposes is an indication of its great popularity. It has quality we have never known in any other variety. One of its most outstanding characteristics is the strong central stalk which, through fair weather and foul, seems to have the ability to produce large, handsome fruit and which is sturdy enough to keep that fruit out of the mud.

It is the size of Rutgers that has won it its host of friends. Growers everywhere who had difficulty in developing size, have been particularly enthusiastic, and have swung a large part of their acreage to Rutgers.

In the Stokes strain of Rutgers, we have endeavored to maintain the erect stalk and size of fruit, while at the same time constantly trying for deeper and smoother fruit. Rutgers will average two ounces heavier than Stokesdale or Master Marglobe but we must admit that it is rougher and flatter. Some of our trade has found it too rough for satisfactory lug box or climax basket packing. Others of our trade have been very thankful for the extra size. Friends of our company who examined our stock this past summer, rated it as the finest they had ever seen.

The Stokes strain of Rutgers, 1940 crop, is, in our opinion, the most perfect type we have yet grown, and is recommended both to the green-wrap trade and to canners. Rutgers has proved especially valuable to canners because of its dark-red interior, which has been much sought after. This color factor has been extremely important, especially in the manufacture of Tomato products. Canners in New Jersey, Pennsylvania, the Eastern Shore of Delaware, Maryland and Virginia, and in Ohio and Indiana have had special success with it.

Rutgers is five days to a week later in maturing than Master Marglobe. For that reason, our customers in the northern-tier states must handle it with caution. It has not been successful when grown where the season is too short.

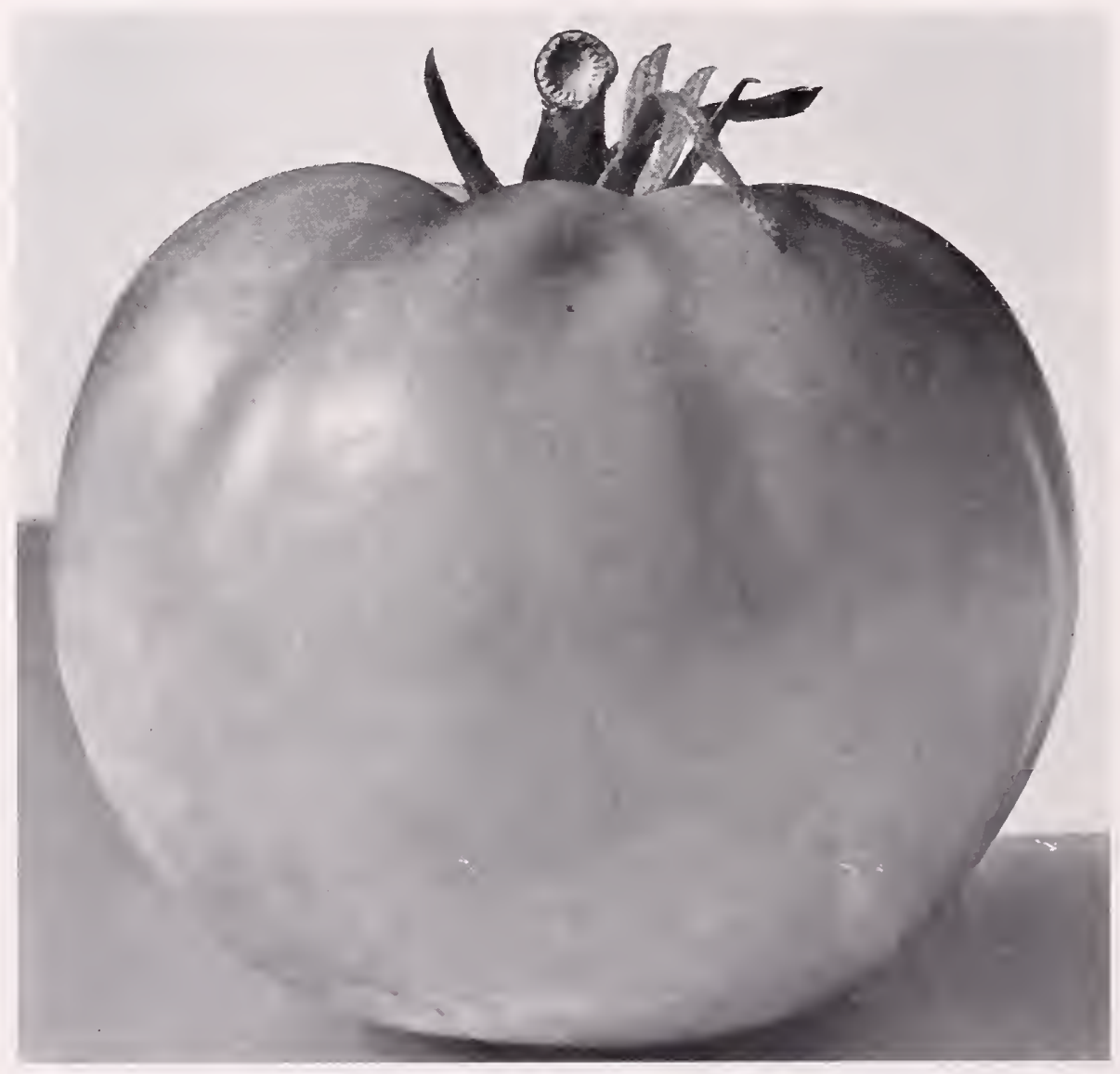

Average weight, 8 ounces. Ratio, depth-to-width, 86 per cent. Average number of fruit, 26. Days to maturity, 122.
PRICE, POSTPAID:

Trade pkt. 25 cts.; oz. 50 cts.; $1 / 4$ lb. \$1.50; lb. \$5;

5 lbs. $\$ 22.50$
Paired with Rutgers, your Stokesdale makes a most satisfactory combination for any truck farmer. Of course, Master Marglobe, in my estimation, is a superior shipping Tomato, although I can see no reason for any farmer wanting a finer strain of Tomato than your Stokesdale. Most hands of your Stokesdale developed several Tomatoes of over 3 -inch diameter-truly a wonderful sight to any truck farmer.-E. H. B., Bloomsburg, Pa.

We are very well pleased with our crop of Tomatoes, the seed of which was purchased from your seedhouse. Valiant produced a heavy crop of Tomatoes, as did the Stokes Master Marglobe and the Rutgers. This is October 24 and we are still able to pick perfect Tomatoes. We have built up a fine trade for such good produce. You may feel assured that you will receive our Tomato seed order for 1939.-W. H. D., Milan, Mich.

Your seed proved very satisfactory for me this year. The Master Marglobe and Rutgers produced excellent fruit. I was very well pleased with the results, both in quality and production.-R. B., Westover, Md. 


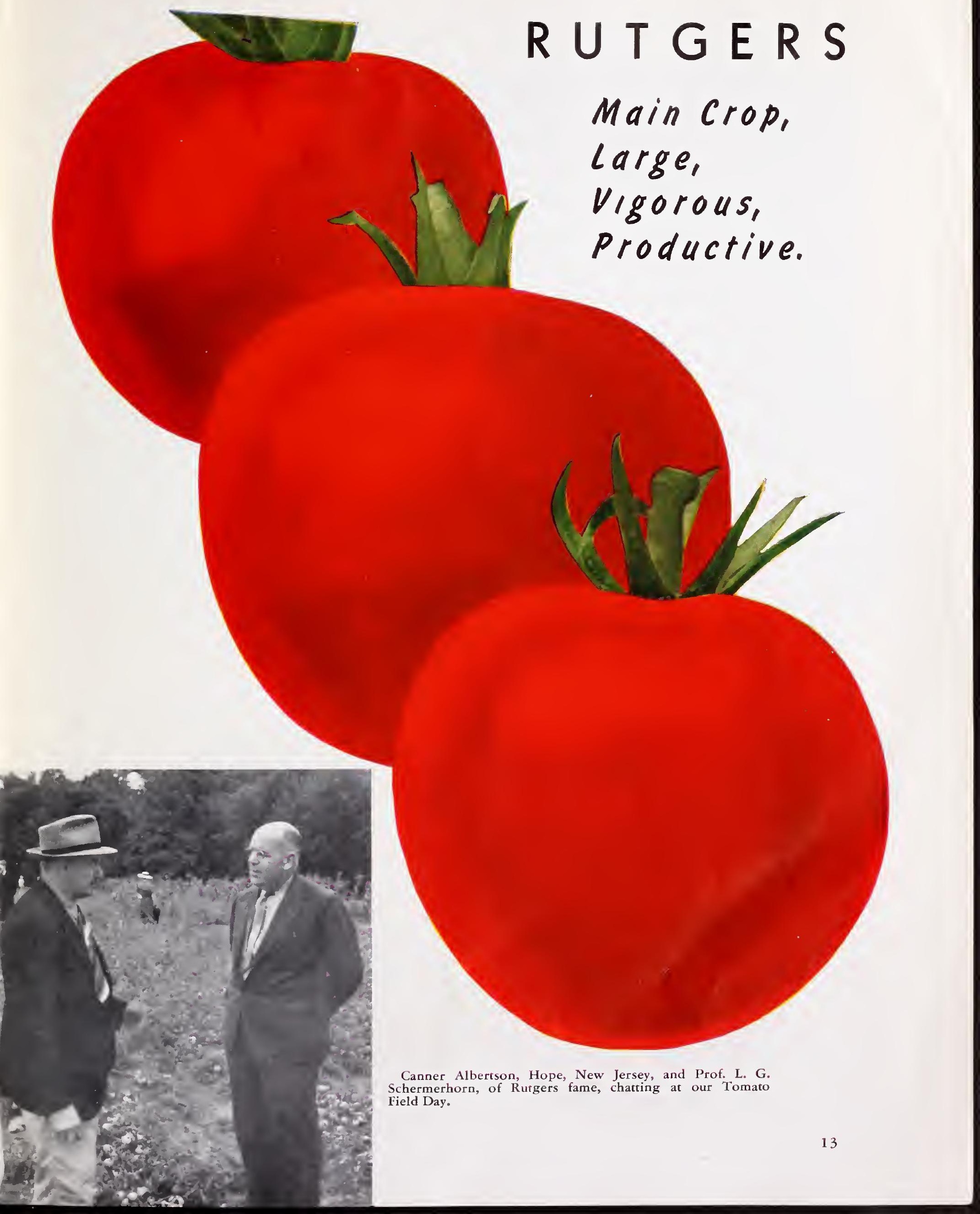




\section{LANGE'S EARLIANA - Our Earliest Maturing Tomato}

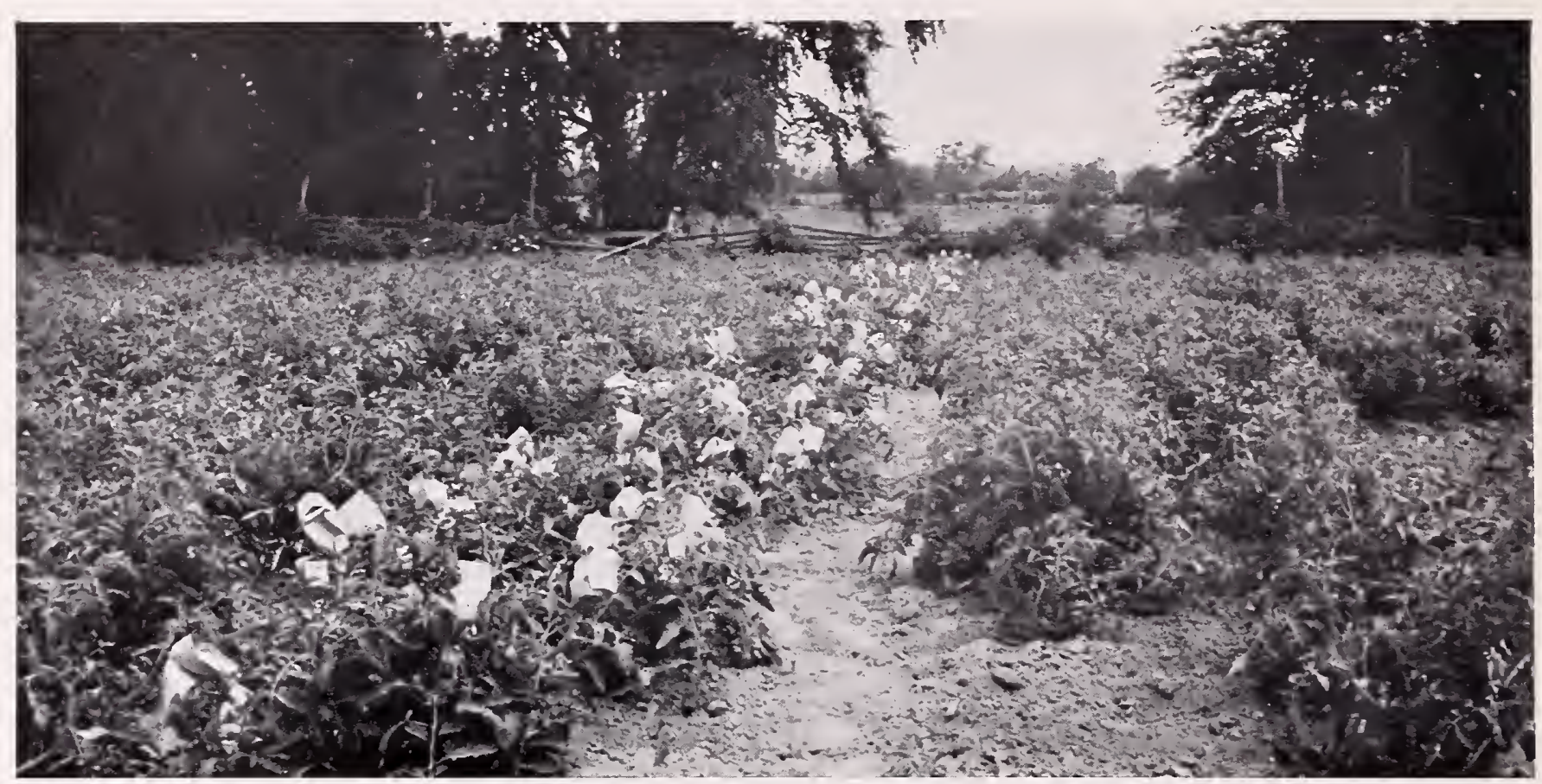

Hybridized and bagged Master Marglobe at Stokesdale Proving Grounds

Ontario-Grown.

Days to maturity, 104.
Ratio, depth-to-width, 75 per cent.

Average weight, 4 ounces.

A VASTLY improved selection out of the Spark's Earliana introduced by Johnson \& Stokes in 1900. The A seed we are offering this year has been grown for us in Ontario by our Canadian associates, Stokes Seeds Limited. In our opinion, it is the earliest and smoothest stock of Lange's Earliana we have ever offered. The success of the variety is due to its ability to produce fully half of its crop during the first ten days of harvest. The crown-set is exceptionally heavy and the fruit is unusually smooth and deep for Earliana.

Price, postpaid: Trade pkt. 25 ets.;

oz. 50cts.; 1/4lb. \$1.50; lb. \$5;

5 lbs. $\$ 22.50$

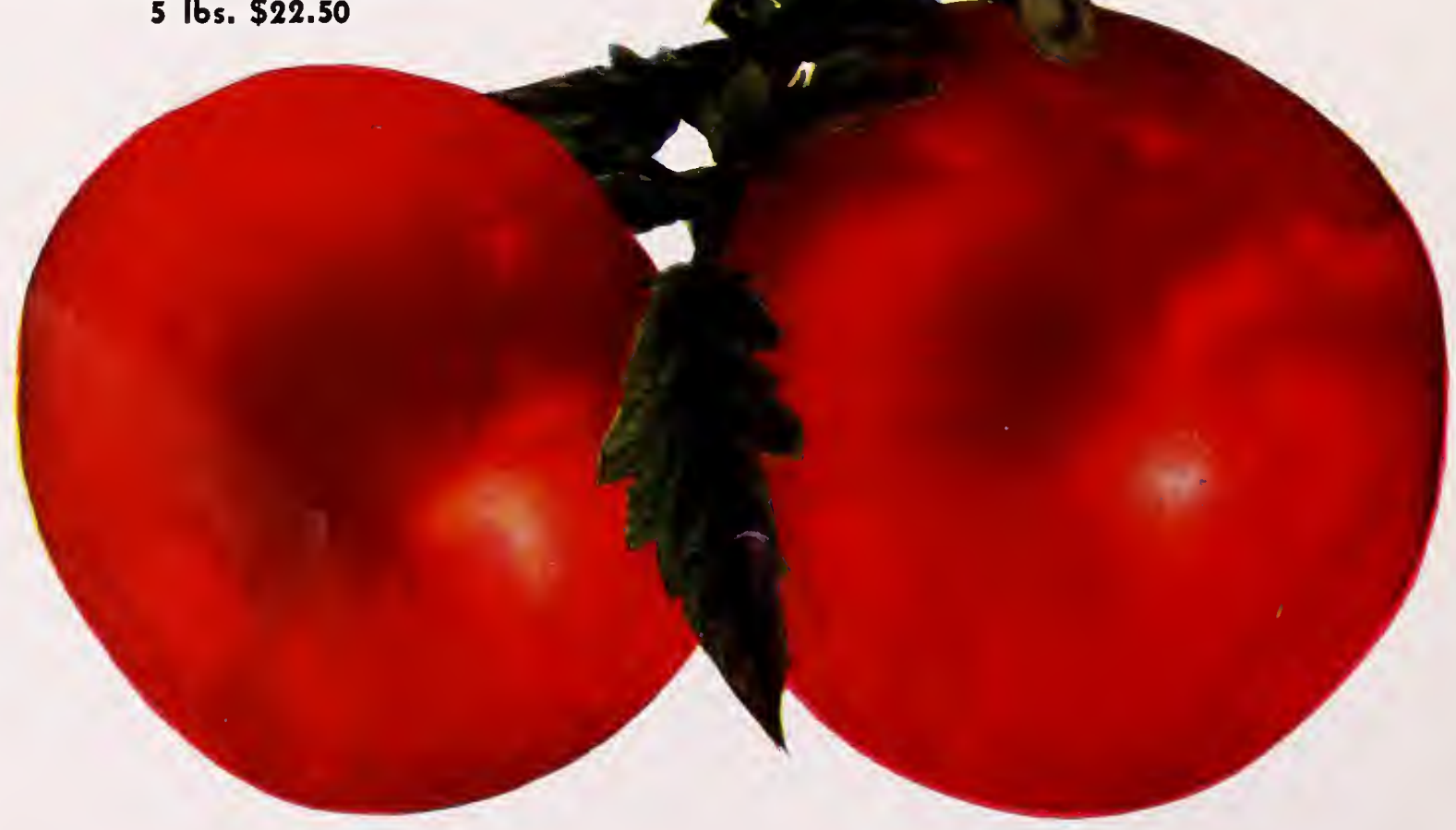




\section{VALIANT-Extra Early Extra Large - Extra Smooth}

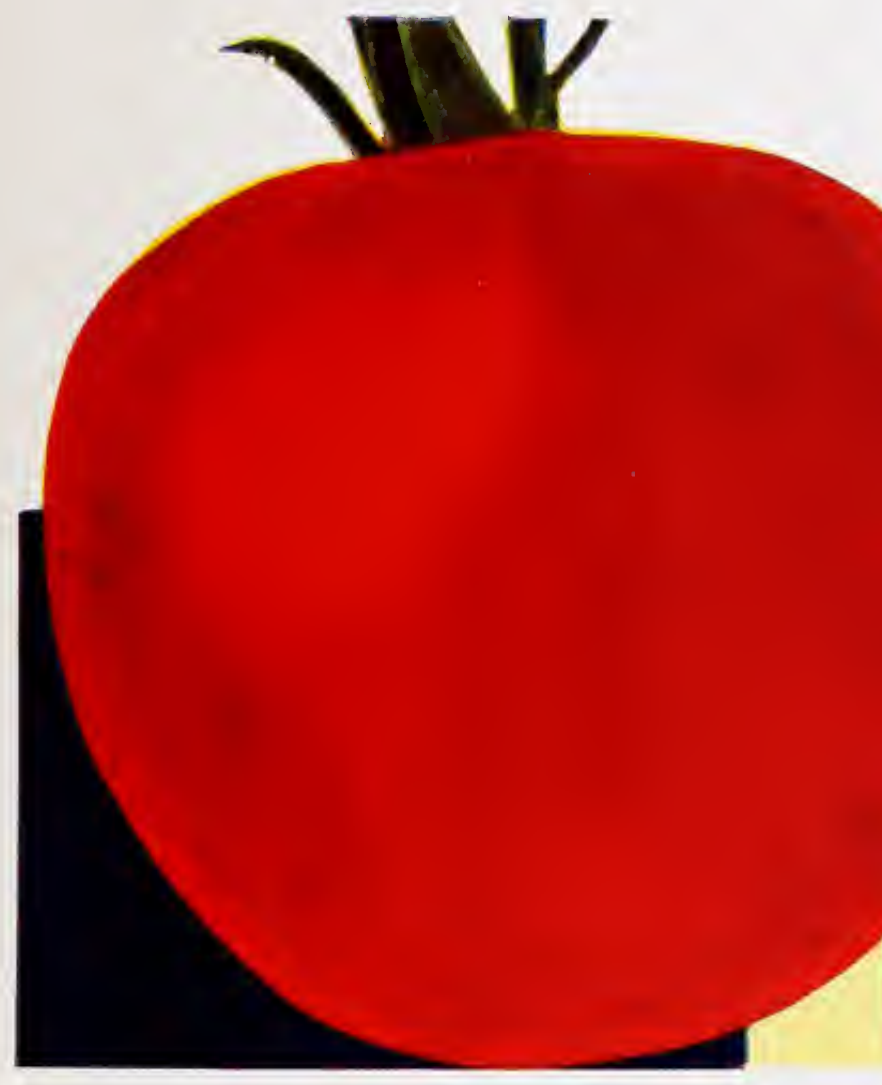

Ratio, depth-to-width, 90 per cent. Days to maturity, 108. Average weight, 8 ounces.

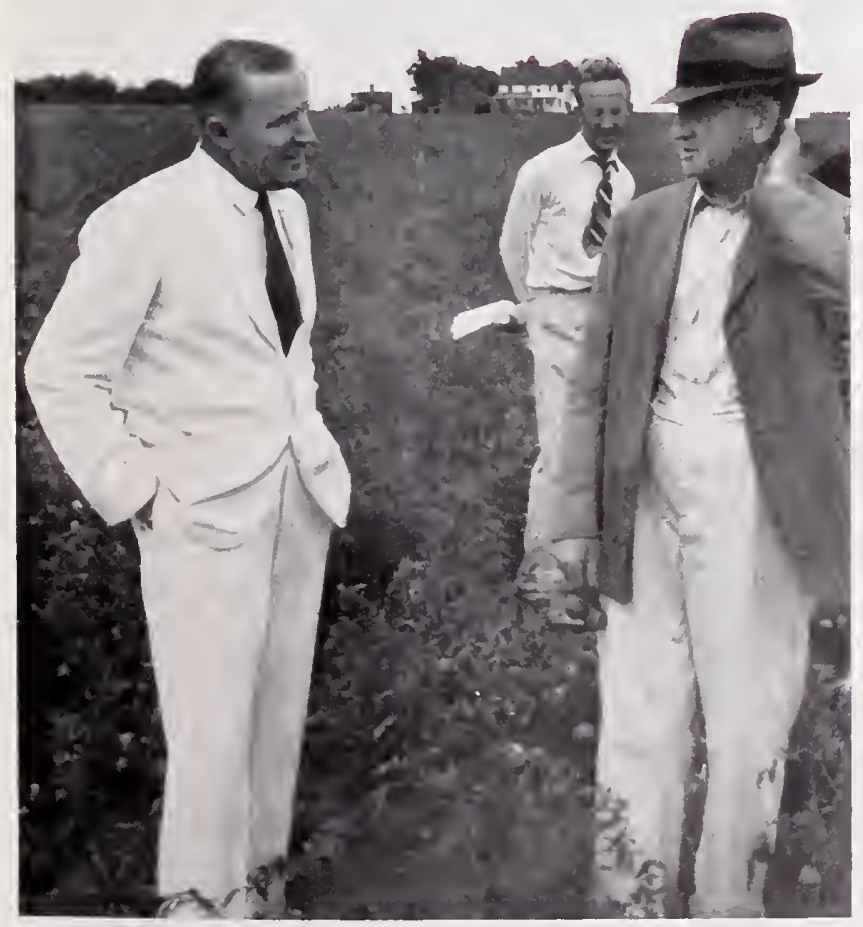

F. C. Stokes, A. A. Foster and T. Wood Wyne at our 1940 Field Day. Valiant has been a consistent money-maker for
Mr. Wyne, a prominent Gloucester County Tomato grower.
Fertilizer Recommendations for Valiant

Valiant, which is grown primarily as an early market Tomato, should have the 1000 pounds of $0-16-0$ or $2-16-0$ application with a quick side dressing of 400 pounds of $10-0-15$ and later side dressings of $10-0-15$ if the plants seem to lose vigor.

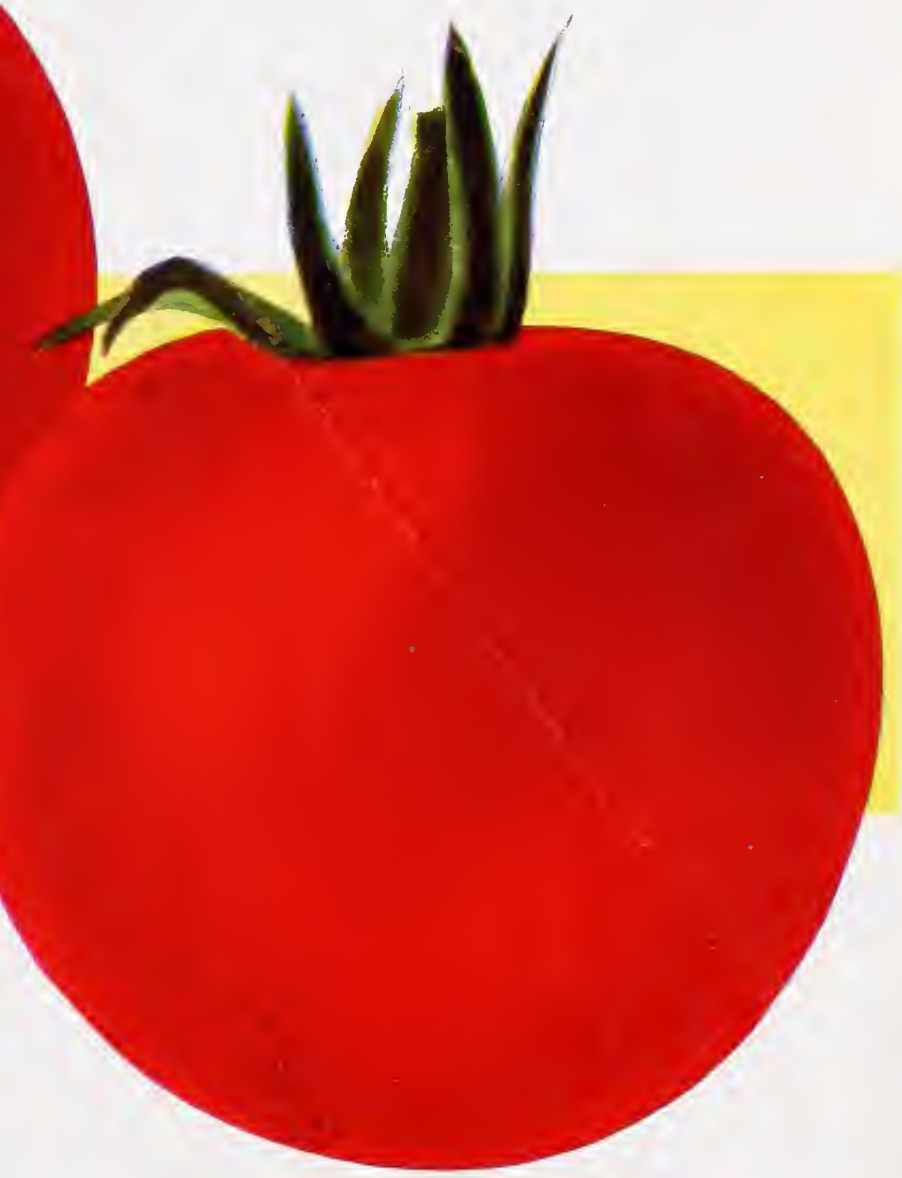

TN MANY districts, Valiant is fast replacing the Earliana 1 types. The four additional days' time that is required for its maturity is quickly overlooked when the market returns come in. Valiant has a sparse, open vine and therefore will never be an all-purpose Tomato, but in its limited field, where it can be matured without too much danger of sunburn, it is already greatly prized.

By the use of hotbed-grown, blocked plants, Valiant, under average New Jersey conditions, matures most of its crop before the severe July heat. The fruit is so smooth and deep that in many cases it is marketed in the Marglobe class. With proper feeding on heavier soils, we have seen Valiant develop an almost normal vine-coverage.

Valiant, a Stokes 1936 introduction, is now in its ninth generation. It is a half-brother of Stokesdale, being a selection out of that remarkable variety. The fruit is unusually large in comparison with the vine, is solid and of brilliant scarlet color. Valiant is not recommended as a cannery type, nor is it recommended for production where it cannot be matured under normal temperatures. In its field, however, it has made a handsome profit for those who have handled it properly. We recommend that a planting of Stokesdale should always follow Valiant.

Valiant was the best Tomato we ever had. Very solid, free from cracks, and of excellent flayor. As to earliness, they were not enough behind EarliC. J. T., Auburn, Me.

Price, postpaid: Trade pkt. 50 cts.; oz. \$1; $1 / 4 \mathrm{lb}$. \$3; Ib. \$10; 5 Ibs. $\$ 45$ 
Are We Downbearted?

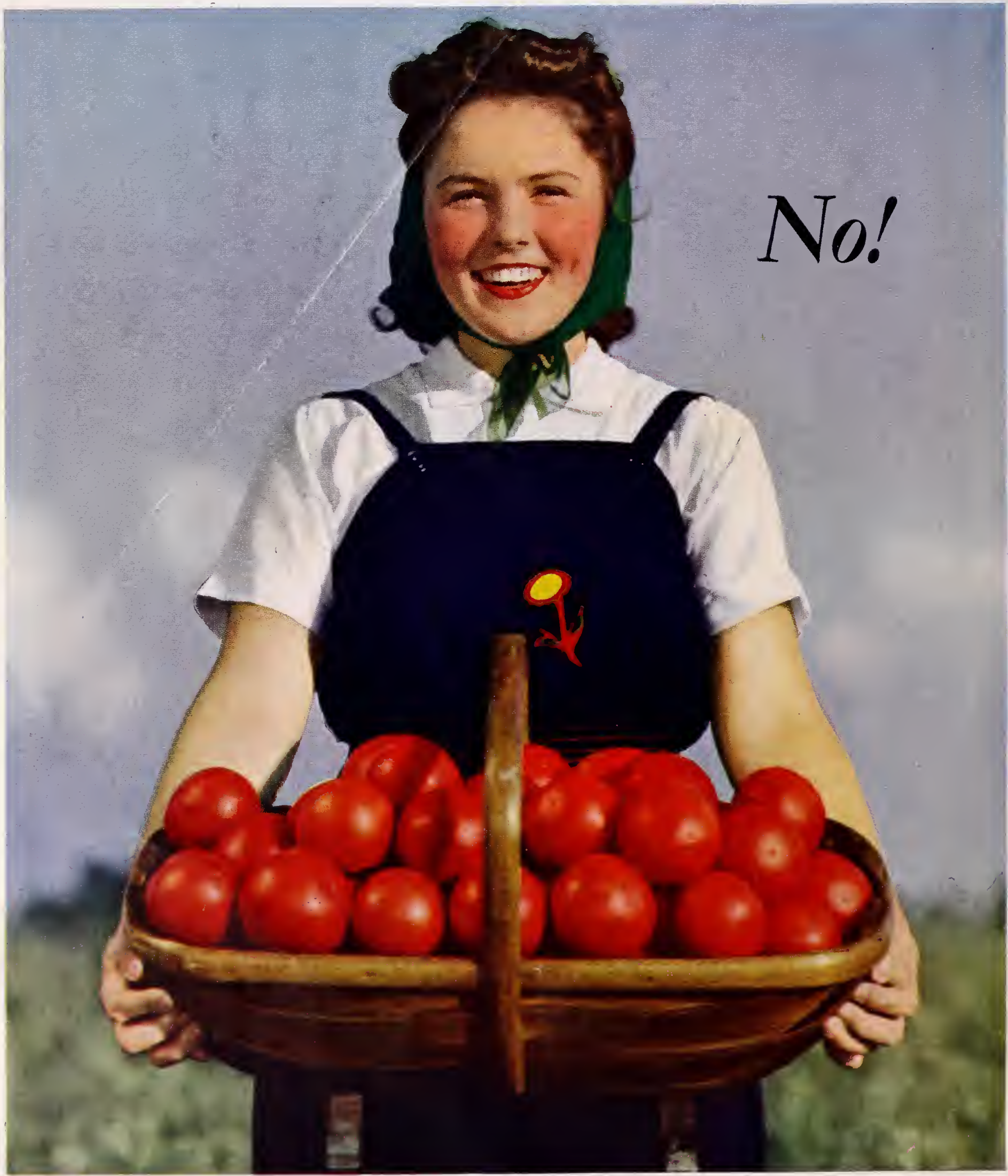

